\title{
Digestion of proteins of varying degradability in sheep. 1. Fermentation in and rate of passage from the reticulorumen
}

J. van Bruchem, S. M. G. Rouwers, G. A. Bangma, C. P. Leffering and P. W. M. van Adrichem

Department of Animal Physiology, Agricultural University, Haarweg 10, 6709 PJ Wageningen, Netherlands

Received 7 August 1984; accepted 24 April 1985

Key-words: volatile fatty acids, NGR, ammonia, dilution rate, buffering capacity

\section{Summary}

Mixed concentrates of which the protein degradability varied were fed to sheep provided with a cannula in the dorsal rumen sac. With increasing degradability of the protein the following effects on rumen fermentation and dilution rate were found. Rumen fermentation was less stabilized. The diurnal variation and content of ammonia in rumen liquids were increased. The ratio of non-glucogenic to glucogenic volatile fatty acids (VFA) decreased. The dilution rate of the rumen liquids increased.

\section{Introduction}

In high-producing dairy cows, protein is usually regarded as the most important nutrient next to energy (Tamminga, 1981a). The amino acids required for maintenance and production are derived from the protein degradation and absorption process in the small intestine. In ruminants, feed ingested is subjected to an extensive microbial degradation in the forestomachs. A proportion of the intermediates and end-products of this degradation process is re-utilized for the production of microbial biomass, bacteria being regarded as the main source of microbial protein. Thus the intestinal protein supply is determined by the microbial protein synthesized in the forestomachs, the undegraded feed protein and a considerable quantity of endogenous protein (van 't Klooster \& Boekholt, 1972).

In recent years it became evident that there are ways to manipulate intestinal protein supply. To a limited extent this can be achieved by reducing the rate of dietary protein degradation in the forestomachs, either by processing the feed or by selecting less easily degradable protein sources. Intestinal protein supply also depends on the rate and efficiency of microbial protein synthesis, which depend 
among other factors on the type and degradability of the substrates available for fermentation. A less stabilized fermentation activity may affect microbial protein synthesis in a negative way (Tamminga, 1981b; Hobson \& Wallace, 1982).

The extent to which the dietary protein is degraded in the forestomachs depends also on the time the feed is retained in the forestomachs and thus on the level of feed intake. The present paper describes the fermentation pattern in the forestomachs and the rate of passage of the digesta to the omasum in sheep fed diets varying in protein degradability.

In a qualitative sense the digestion processes in dairy cows and sheep are very similar. In quantitative terms, however, the extent of protein digestion in dairy cows may be considerably lower than in sheep (Schiemann et al., 1971). Nevertheless, the results of this study may be applied to rank the proteins according to their degradability as related to retention time and fermentation in the forestomachs. In dairy cows fed at a higher level the quantity of dietary protein escaping rumen degradation is probably increased, especially of less easily degradable proteins (Ørskov \& McDonald, 1979).

\section{Materials and methods}

Two mature Texel wethers with a live weight of about $70 \mathrm{~kg}$ were fitted with a hard pvc cannula (i.d. $25 \mathrm{~mm}$ ) into the dorsal rumen sac. During the experiments the sheep were kept in pens $(1.5 \mathrm{~m} \times 2 \mathrm{~m})$. In order to achieve a regular flow of digesta through the gastrointestinal tract, the feed was offered over the day in six equal portions $(4.00,8.00,12.00,16.00,20.00$ and $24.00 \mathrm{~h})$. Water was available in excess. Care was taken that the sheep had well recovered from surgery and had been well accustomed to the whole experimental routine.

With groundnut expeller (GE), potato protein (PP), peas (PE) and dried breweries grains $(\mathrm{BG})$ mixed concentrates were composed of which the rumen degradability of the protein varied. In total six rations were composed (Table 1). The mixed concentrates $(600 \mathrm{~g} / \mathrm{d})$ were supplied together with rye grass straw $(300 \mathrm{~g} / \mathrm{d})$. The chemical composition of the rations including rye grass straw is given in Table 2 .

Table 1. Composition of the mixed concentrates $(\mathrm{g} / \mathrm{kg})$.

\begin{tabular}{lcrrrrr}
\hline & GE (2) & PP (2) & GE (1) & PP (1) & PE (1) & BG (1) \\
Groundnut expeller & 600 & & 210 & & & \\
Potato protein & & 450 & & 160 & & \\
Peas & & & & & 600 & \\
Breweries grains & 150 & 225 & 345 & 370 & 150 & 150 \\
Sugar-beet pulp & 150 & 225 & 345 & 370 & 150 & 150 \\
Citrus pulp & 80 & 80 & 80 & 80 & 80 & 80 \\
Sugar-beet molasses & 20 & 20 & 20 & 20 & 20 & 20 \\
Minerals/vitamins & 51 & 7 & 35 & 10 & 46 & 13 \\
& \\
Protein solubility (\%) & 51 & & & & & \\
\hline
\end{tabular}


Table 2. Chemical composition of rye grass straw (RGS) and mixed concentrates ( $\mathrm{g} / \mathrm{kg}$ dry matter).

\begin{tabular}{llrrrr}
\hline & OM & XP & XL & XF & XX \\
RGS & 914 & 44 & 15 & 377 & 478 \\
GE (2) & 934 & 377 & 50 & 83 & 423 \\
PP(2) & 946 & 384 & 16 & 87 & 459 \\
GE (1) & 930 & 181 & 28 & 125 & 596 \\
PP (1) & 936 & 199 & 19 & 125 & 593 \\
PE (1) & 935 & 172 & 18 & 80 & 665 \\
BG (1) & 942 & 175 & 50 & 139 & 578 \\
\hline
\end{tabular}

1 OM: organic matter; XP: crude protein; XL: crude fat; XF: crude fibre; XX: N-free extract.

Table 3. Experimental design, according to which the rations were randomised over the sheep.

\begin{tabular}{lll}
\hline $\begin{array}{l}\text { Experimental } \\
\text { period }\end{array}$ & Sheep 1 & Sheep 2 \\
1 & & \\
2 & GE (2) & PP (2) \\
3 & PP (2) & GE (2) \\
4 & GE (1) & PP (1) \\
5 & PP (1) & GE (1) \\
6 & BG (1) & PE (1) \\
\hline
\end{tabular}

The solubility of the protein was estimated according to Wohlt et al. (1973) and is given in Table 1 . The experimental design, according to which the rations were randomized over the sheep, is given in Table 3 .

The dilution rate of the liquid reticuloruminal contents was estimated with CrEDTA (Binnerts et al., 1968), of which $50 \mathrm{ml}(8.6 \mathrm{Cr} / \mathrm{l})$ was injected into the ventral rumen sac. Samples were taken from the liquid contents of the ventral rumen sac over a 7 -h period with 1 -h time intervals. The dilution rate $(k)$ was calculated assuming an exponential decline of the marker concentration:

$$
\mathrm{C}_{t}=C_{0} \cdot \mathrm{e}^{-k t}
$$

In this model $\mathrm{C}$ represents marker concentration, $k$ the dilution rate of the rumen liquids and $t$ the time interval elapsed since marker injection. The theoretical marker concentration at the time of marker injection $\left(C_{0}\right)$ can be calculated by linear regression after logarithmic transformation of $(1)$ :

$$
\ln C_{t}=\ln C_{0}-k t
$$

With $C_{0}$ and the amount of marker injected the volume $(V)$ of the liquid reticuloruminal contents can be estimated and subsequently the flow (F) into the omasum:

$$
F(\mathrm{ml} / \mathrm{h})=V(\mathrm{ml}) \times k\left(\mathrm{~h}^{-1}\right)
$$


For the determination of the $\mathrm{pH}$ and buffering capacity and the concentration of ammonia and the volatile fatty acids, per day four samples were taken from the ventral rumen sac, starting one hour after feeding $(09 \mathrm{~h} 00)$ and with 1-h intervals.

In these samples the analyses were performed as follows:

- the pH and buffering capacity according to Counotte et al. (1979);

- ammonia following the method of Berthelot with phenol and hypochlorite. The extinction of the resulting blue colour was estimated at $623 \mathrm{~nm}$ with a Perkin Elmer $55 \mathrm{E}$ spectrophotometer;

- the volatile fatty acids by gas liquid chromatography (Packard 419, glass column filled with chromosorb 101, carrier gas saturated with formic acid);

- Cr after proper dilution with an atomic absorption spectrometer (Perkin Elmer $360)$ at $357.9 \mathrm{~nm}$, following the method of standard addition.

The data were analysed statistically by a two-sampled analysis of variance, taking into consideration differences between sheep. Student $T$ values for testing significances can be calculated dividing contrasts between rations by SEM $\times \sqrt{2}$ (d.f. $=41)$.

\section{Results}

The volume of the liquid ruminal contents as determined by Cr-EDTA dilution showed to increase during the course of the experiments. As a consequence also the rate of passage of digesta to the omasum increased. Coinciding with this unexpected increase in volume the buffering capacity $(\beta)$ of the rumen liquids and the mean concentration of ammonia and the volatile fatty acids (VFA) decreased. These differences caused by the change in rumen volume do not necessarily reflect differences in the rate of fermentation between rations. In Fig. 1, $\beta$, calculated as the mean of 4 estimates in a between feeding interval, is presented graphically, showing that the increase in rumen volume caused the most distinct decrease of $\beta$ between $\mathrm{pH} 4.5-5$. Since here $\beta$ is predominantly determined by VFA, it seems that the decrease is caused by dilution, probably as a result of an increased salivary flow causing $\beta$ to increase at $\mathrm{pH} 6.25$.

Because of this drift in rumen volume during the course of the experiments the least degradable rations (PP and $\mathrm{BG}$ ) can best be compared with the more easily degradable rations (GE and $\mathrm{PE}$ ) fed in the same experimental period. In Fig. 2, $\beta$ is presented graphically as affected by ration composition and time after feeding. PP and BG induced slightly less pronounced fluctuations when compared at feeding time with $1 \mathrm{~h}$ thereafter, the times with the lowest and highest rates of fermentation, respectively. One hour after feeding an increased rate of fermentation and a concomitant rise in VFA concentration caused $\beta$ to be increased at $\mathrm{pH} 4.75$ and to be decreased at $\mathrm{pH} 6.25$ by bicarbonate ions trapping the VFA hydrogen ions.

With the least degradable rations (PP and $\mathrm{BG}$ ) the mean ammonia concentration in rumen liquids was lower (Table 4) and fluctuations in relation to feeding time were less pronounced (Fig. 3). The ratio of non-glucogenic to glucogenic VFA, calculated as the NGR value, according to Ørskov (1975), was higher for the least degradable diets, however with the exception of PE. Fluctuations of NGR in relation 


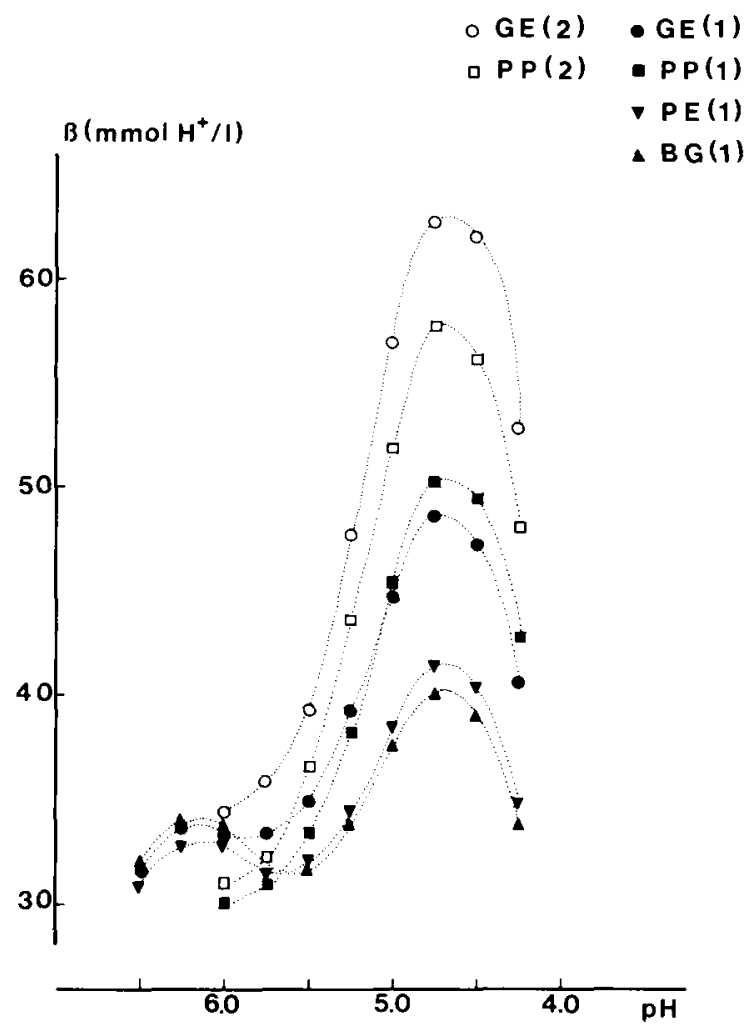

Fig. 1. Buffering capacity of rumen liquids as affected by ration composition.

to feeding time were less pronounced. There was no significant effect on total VFA concentration and its variability. However, of the branched chain VFA and valeric acid, typical protein breakdown products, the mean concentration was lower and also less variable.

Feeding the least degradable rations resulted in a higher retention time of the liquids in the rumen (Table 4), in general together with an increased rumen volume and rate of passage of digesta into the omasum.

With regard to the protein content of the ration the following was noticed. A higher protein content (2) caused increased ammonia levels, the response being most significant with GE, the ration with the higher degradability. Besides, with the lower protein content (1) the NGR values were higher.

\section{Discussion}

The quantity of protein entering the small intestine of ruminants depends on both the extent of protein degradation and microbial protein synthesis in the forestomachs. The rations used in the present experiments varied in degradability. The 

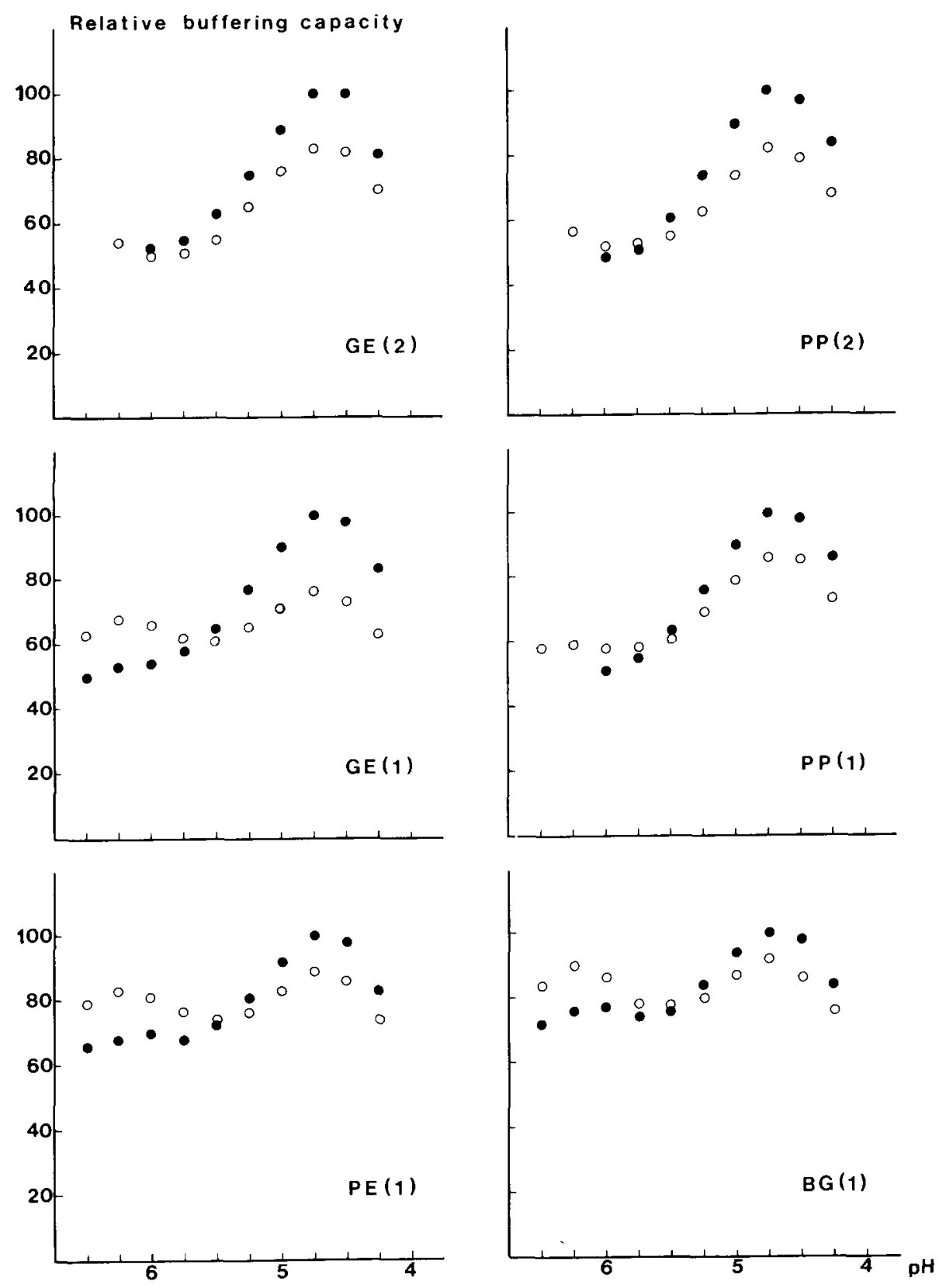

Fig. 2. Relative buffering capacity of rumen liquids as related to ration composition and feeding time $(\mathrm{O}$ : at feeding; $1 \mathrm{~h}$ after feeding). 

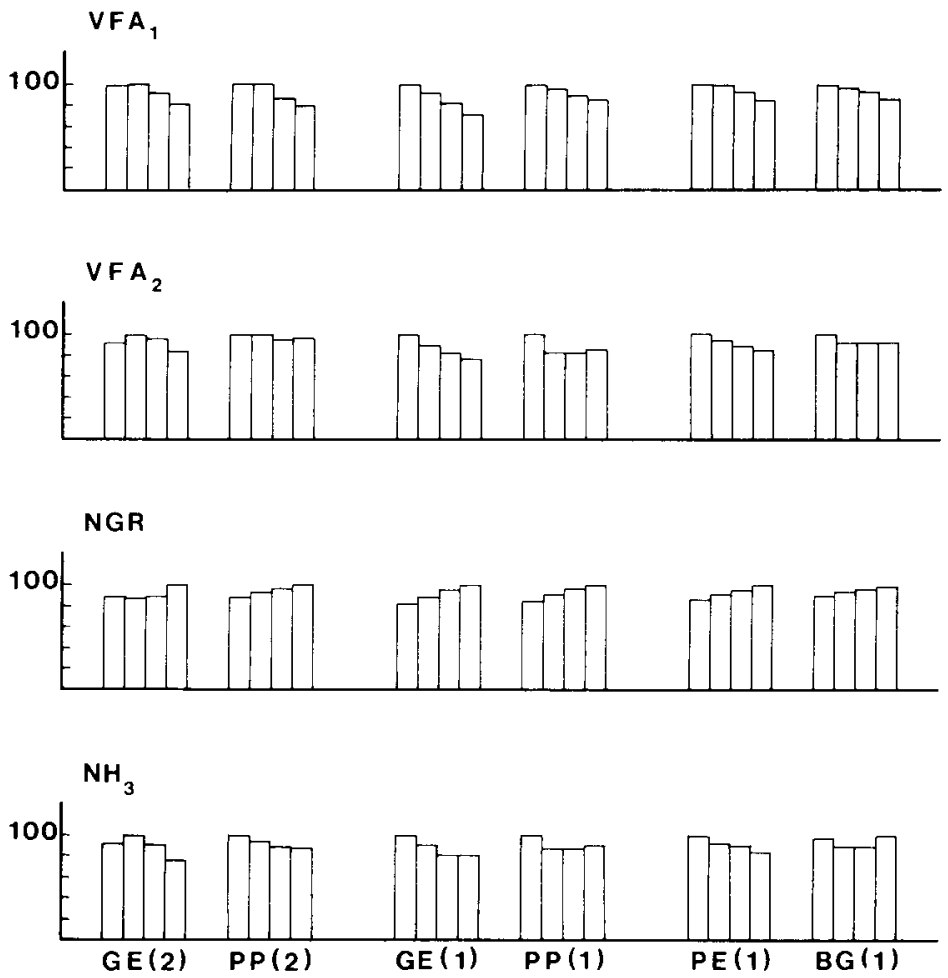

Fig. 3. Relative values of total VFA (VFA1), branched chain VFA plus valeric acid (VFA2), the ratio of non-glucogenic to glucogenic VFA (NGR) and ammonia in rumen liquids, as affected by ration composition and feeding (bars from left to right 3,2 and $1 \mathrm{~h}$ prior to, and at feeding, respectively).

Table 4. Rumen characteristics of sheep fed rations differing in protein degradability (mean values with their standard error).

\begin{tabular}{lccccccc}
\hline & GE (2) & PP (2) & GE (1) & PP (1) & PE (1) & BG (1) & SEM \\
& & & & & & & \\
Volume $(\mathrm{l})$ & 3.07 & 4.39 & 5.35 & 6.37 & 7.46 & 7.58 & 0.283 \\
Dilution rate $(\% / \mathrm{h})$ & 11.6 & 10.0 & 10.8 & 8.6 & 10.0 & 8.6 & 0.39 \\
Flow $(\mathrm{ml} / \mathrm{h})$ & 352 & 435 & 578 & 535 & 750 & 652 & 22.9 \\
$\mathrm{pH}^{1}$ & 6.57 & 6.39 & 6.63 & 6.46 & 6.65 & 6.66 & 0.070 \\
Acetate $^{1}(\mathrm{mmol} / \mathrm{l})$ & 58.4 & 56.7 & 47.3 & 50.8 & 41.6 & 40.4 & 1.60 \\
Propionate $^{1}(\mathrm{mmol} / \mathrm{l})$ & 19.4 & 17.2 & 14.7 & 14.5 & 9.2 & 10.3 & 0.62 \\
Butyrate $^{1}(\mathrm{mmol} / \mathrm{l})$ & 11.6 & 10.2 & 8.8 & 9.0 & 8.4 & 6.2 & 0.45 \\
Isobutyrate $^{1}(\mathrm{mmol} / \mathrm{l})$ & 1.17 & 1.09 & 0.58 & 0.48 & 0.46 & 0.41 & 0.041 \\
Isovalerate $^{1}(\mathrm{mmol} / \mathrm{l})$ & 1.69 & 1.53 & 0.65 & 0.54 & 0.64 & 0.46 & 0.069 \\
Valerate $^{1}(\mathrm{mmol} / \mathrm{l})$ & 1.38 & 0.94 & 0.65 & 0.59 & 0.47 & 0.54 & 0.046 \\
NGR of $\mathrm{VFA}^{1.2}$ & 3.86 & 4.16 & 4.21 & 4.67 & 5.93 & 4.84 & 0.128 \\
Ammonia $^{1}(\mathrm{mmol} / \mathrm{l})$ & 33.7 & 17.6 & 9.9 & 7.2 & 7.9 & 6.7 & 0.71 \\
\hline
\end{tabular}

1 Mean of 4 estimates between feeding

$2(\mathrm{HAc}+2 \mathrm{HBu}+\mathrm{HVa}) /(\mathrm{HPr}+\mathrm{HVa})$.

Neth. J. agric. Sci. 33 (1985) 
quantity of dietary protein escaping rumen fermentation gives us a tool to manipulate the host animal's amino acid supply from the small intestine. Since, however, also with less easier degradable proteins, still the major part of the protein entering the small intestine is of microbial origin, also the rate and efficiency of microbial protein production are of great interest. Microbes need energy and a suitable $\mathrm{N}$ source for growth. Under the anaerobic rumen conditions carbohydrates are the most favourable energy substrates.

From proteins less energy can be extracted and fats cannot be utilized for this purpose. For an efficient synthesis of microbial biomass it is desirable that both energy and the $\mathrm{N}$ source come available in a fairly steady rate. If energy is available in excess, spiliage of energy may be the result (Hobson \& Wallace, 1982; Tamminga, 1983). If the dietary protein is degraded fast, ammonia and probably also amino acids will come available in amounts exceeding the rate of incorporation in the microbes. As a result, considerable amounts of $\mathrm{N}$ may be lost from the forestomachs as ammonia. The efficiency of microbial protein production also depends on rumen $\mathrm{pH}$. With the present experiments, the $\mathrm{pH}$ of the rumen contents did not fall to a level that the growth rate of rumen microbes was severely inhibited. Kistner et al. (1979) showed pH optima for important amylolytic and cellulolytic rumen microbes to vary between $\mathrm{pH} 6.0-6.5$. The present high rumen $\mathrm{pH}$ was probably the result of the feed intake level, whereas variability was limited due to the high frequency of feeding. At higher intake levels of concentrates and especially with high degradabilities, carbohydrates are rapidly converted into VFA, causing a severe drop in rumen $\mathrm{pH}$ and probably a decreased rate and efficiency of microbial protein production. With increasing degradability of the ration the ratio of non-glucogenic to glucogenic VFA (NGR) decreases. Larger quantities of non-structural carbohydrates cause considerable quantities of propionate to be produced. On the other hand structural carbohydrates are more resistant to degradation in the rumen resulting in a more steady rate of fermentation and a usually higher proportion of acetate to be produced, a condition that is favourable for milk fat production.

Although the major part of VFA originates from the dietary carbohydrates, more easily degradable proteins were found in the present experiments to induce lower NGR values as well. This is probably a result of a considerable quantity of propionate being derived from the degraded proteins (Counotte, 1979). With the less easily degradable proteins the diurnal variation of NGR showed to be less. For dairy cattle this would imply that VFA come available in a more constant ratio. Less easily degradable proteins induce an increased milk fat production (Bakker et al., 1981), probably coinciding with higher and more steady NGR values (W. A. G. Veen, personal communication).

With increasing protein degradability the concentration and its diurnal variation of ammonia in the rumen increased. Ammonia concentration increased with protein degradability as caused by an increased rate of ammonia release, possibly together with a decreased rate of incorporation into microbial protein. This effect was especially noticed with the higher protein content in the ration. Then the rate of ammonia release was increased but the rate of microbial protein production was not, both in comparison with the lower protein content. This difference was most signifi- 
cant with the more easily degradable protein.

The extent of protein degradation in the forestomachs depends both on protein degradability and the retention time of the protein in the forestomachs. The present results indicated an increased retention time in the forestomachs with the less easily degradable proteins. Although this conclusion is based on the liquid rumen contents, it probably indicates that of the particulate phase the retention times will be in the same order, since the retention times of the liquid and particulate phases have been shown to be related positively (van Bruchem et al., 1984). This means that with the present experiments less easily degradable protein escaped rumen fermentation to a greater extent (van Bruchem et al., 1985a), despite they were retained longer in the forestomachs. So the differences in degradability found were probably smaller than might be expected from properties of the diet.

Under practical conditions, concentrates are offered twice a day. Under the present experimental conditions, sheep were fed at a higher frequency. With a lower feeding frequency the quantity of protein escaping degradation is increased. A higher feeding frequency causes, however, the rate of synthesis of microbial protein to be increased, resulting in a higher passage of total protein in the duodenum (Tamminga, 1981b).

\section{Acknowledgements}

The authors gratefully acknowledge Mr G. van Gelderen for collecting samples and taking care of the cannulated sheep, Mrs S. C. W. Lammers-Wienhoven and Mr W. Onck for skilful analyses, and Prof. S. Tamminga and Dr W. A. G. Veen for advice and discussion during the course of this study.

\section{References}

Bakker, Y. Tj., W. A. G. Veen \& J. P. Cornelissen, 1981. Derde proef omtrent de invloed van de bestendigheid van het krachtvoereiwit op verschillende produktiekenmerken van hoogproduktieve melkkoeien. Proefverslag, CLO-Instituut 'De Schothorst'.

Binnerts, W. T., A. Th. van't Klooster \& A. M. Frens, 1968. Soluble chromium indicator measured by atomic absorption in digestion experiments. Veterinary Records 82: 470.

Bruchem, J. van, A. J. Schutte, G. A. Bangma, C. P. Leffering \& P. W. M. van Adrichem, 1984. Dilution rate of a liquid and particulate phase marker from the reticulorumen of sheep. Canadian Journal of Animal Science 64: 72-73.

Bruchem, J. van, S. M. G. Rouwers, G. A. Bangma, S. C. W. Lammers-Wienhoven \& P. W. M. van Adrichem, 1985a. Digestion of proteins of varying degradability in sheep. 2. Amount and composition of the protein entering the small intestine. Netherlands Journal of Agricultural Science 33: 273284.

Bruchem, J. van, L. J. G. M. Bongers, J. D. van Walsem, W. Onck \& P. W. M. van Adrichem, 1985 b. Digestion of proteins of varying degradability in sheep. 3. Apparent and true digestibility in the small intestine and ileal endogenous passage of $\mathrm{N}$ and amino acids. Netherlands Journal of Agricultural Science 33: 285-295

Counotte, G. H. M., A. Th. van 't Klooster, J. van der Kuilen \& R. A. Prins, 1979. An analysis of the buffer system in the rumen of dairy cattle. Journal of Animal Science 49: 1536-1544.

Counotte, G. H. M., 1981. Regulation of lactate metabolism in the rumen. Thesis, State University, Utrecht. 


\section{J. VAN BRUCHEM ET AL.}

Hobson, P. N. \& R. J. Wallace, 1982. Microbial ecology and activities in the rumen. C.R.C. Critical Review in Microbiology 9: 165-320.

Kistner, A., J. Therion, J. H. Kornelius \& A. Hugo, 1979. Effect of $\mathrm{pH}$ on specific growth rates of rumen bacteria. Annales de Recherches Vétérinaires 10: 268-270.

Klooster, A. Th. van 't \& H. A. Boekholt, 1972. Protein digestion in the stomachs and intestines of the cow. Netherlands Journal of Agricultural Science 20: 272-284.

Ørskov, E. R., 1975. Manipulation of rumen fermentation for maximum food utilization. World Review of Nutrition and Dietetics 22: 152-182.

$\emptyset$ rskov, E. R. \& I. McDonald, 1979. The estimation of protein degradability in the rumen from incubation measurements weighted according to rate of passage. Journal of Agricultural Science, Cambridge 92: 499-503.

Schiemann, R., K. Nehring, L. Hoffmann, W. Jentsch \& A. Chudy, 1971. Energetische Futterbewertung und Energienormen. VEB Deutsche Landwirtschaftsverlag, Berlin.

Tamminga, S., 1981a. Nitrogen and amino acid metabolism in dairy cows. Thesis, Agricultural University, Wageningen.

Tamminga, S., 1981b. Effect of frequency of feeding concentrate diets on $\mathrm{N}$ entering the small intestine of dairy cows. Proceedings, Amino Acid Symposium, Warsaw.

Tamminga, S., 1983. Recent advances in our knowledge on protein digestion and absorption in ruminants. In: M. Arnal, R. Pion \& D. Bonin, Proceedings 4th EAAP Symposium on Protein Metabolism and Nutrition. (Clermont-Ferrand, 5-9 September 1983). EAAP publication No 31, Vol I: 263-288.

Wohlt, J. E., C. J. Sniffen \& W. H. Hoover, 1973. Measurement of protein solubility in common feedstuffs. Journal of Dairy Science 56: 1052-1057. 